\title{
アレルギー性疾患に伴う神経障害
}

\section{吉良 潤一}

要 旨

アレルギー性疾患に伴う神経障害としては,全身性血管炎の一環として多発性単神経炎を呈するChurgStrauss症候群がよく知られている.本症候群では,まれに脳出血や脳梗塞を合併する以外には中枢神経 が侵されることはない。このように，従来，アレルギー性疾患と中枢神経障害の関連は考えられていな

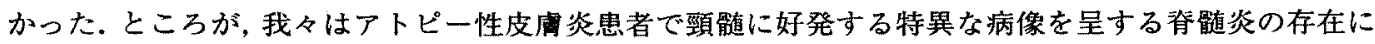

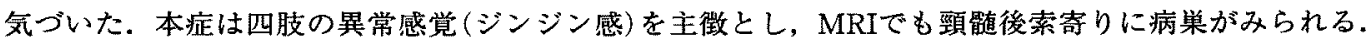
臨床的にもMRI上の病巣においても長く存続するのが特徴である. 脊髄病理は, 好酸球性炎症で軸索も 髄鞘も傷害される. 我々はアトピー素因を背景にして起こる脊䯋炎との意で,アトピー性奉䯣炎との病 名を提唱している. 本症の発見を契機として, 頸髄前角連動ニューロンを侵す平山病と気道アレルギー の関連が明らかにされるなど，アトピー菜因と脊檤障害の関連を示す成績が次第に蓄積されつつある。

〔日内会誌 $93: 1017 \sim 1025,2004$ ]

Key words：脊䯑道炎，アレルギーアトピー, 平山病, Hopkins症候群

\section{はじめに}

近年, 先進諸国ではアレルギー性疾患の頻度 が著しく増加し,大きな社会問題となっている. アレルギー性疾患の背景として，アトピー素因 が重要である。アトピー素因とは，ダニ抗原や スギ花粉など環境中の普遍的な抗原に対して高 IgE応答を呈する状態である.アレルギー性疾患 に伴う神経障害としては，末梢神経障害を呈す るChurg-Strauss症候群がよく知られている。一 方,アレルギー性疾患に伴う中枢神経障害とし ては，まれに小児で気管支喘息の発作後にポリ 才様の弛緩性麻痺を呈することがあり, Hopkins 症候群と呼ばれている1)。しかし,成人ではアレ ルギー性疾患に伴って中枢神経障害が起こると

きらしゅんいち：九州大学大学院医学研究院神経内 科
は全く考えられていなかった. ところが，我々 はアトピー性皮覤炎に伴い特異な病像を示す春 䯣炎を発症する例があることを初めて報告した。 これを契機にアレルギーと中枢神経の器質的障 害の関連を示す知見が次第に蓄積されつつある. 本稿では，このようなアレルギーに伴う中枢神 経障害の最新の知見に力点をおいて概説する.

\section{Churg-Strauss症候群に伴う多発性単 神経炎}

本症候群は, 1951 年にChurgとStraussにより 古典的多発動脈炎から独立した概念として提唱 された2).アレルギー性肉芽腫性血管炎 (allergic granulomatous angiitis）とも呼ばれ，中小動 脈を主病変とする血管炎がその本態である．難 治性の気管支喘息が先行した後に，好酸球増多 を呈し, 30 歳代から 40 歳代にかけて全身性の血 管炎を生じる。血管炎による症状としては, 発 
熱, 体重減少, 消化管出血, 紫斑, 関節痛, 筋 肉痛, 腎障害, 心外膜炎，心筋梗塞などを呈す る.血管资を呈する時期には喘息は沈静化して いることが多い.

本症では，血管炎の重要な現れとして高率に 末梢神経障害を生じる、末梢神経障害は, 末梢 神経の栄養血管の血管炎により，多発性単神経 炎を呈する ${ }^{3)}$. 末梢神経の走行に沿って強い痛み が起こり, 四肢遠位部の異常感覚と浮腫を呈す る．末梢神経支配領域の感覚障害，筋脱力と筋 萎縮がみられる．末梢神経伝導速度検查では， 振幅が著明に低下する軸索障害パターンを呈す る.

病理学的には，著明な好酸球浸潤を伴うフィ ブリノイド壊死性血管炎がみられる，生検され た腓腹神経は血管炎所見に加えて軸索の脱落， 変性を呈する，好酸球とCD4 陽性 T細胞, CD8 陽性T細胞が主に浸潤する.活性化好酸球の産物 である eosinophil cationic proteinやmajor basic proteinの組織沈着がみられ ${ }^{3.4)}$, 血管外肉芽腫を 伴うことがある．検查所見では，好酸球增多に 加えて, 血清IgE増加 $(600 \mathrm{U} / \mathrm{ml}$ 以上) がみられ, 抗好中球細胞質抗体 (myeloperoxydase specific antineutrophil cytoplasmic autoantibody; MPOANCA）が高率（50～85\%）に陽性となる．他 に白血球增多 $(1$ 万 $/ \mu 1)$, 血小板堌加 $(40$ 万 $/ \mu 1)$, リウマチ因子陽性, 肺浸潤影などの検查異常を 伴う。

本症では，まれに脳出血や脳梗塞を合併する 以外には中枢神経障害を呈することはない，本 症に伴って脊髓炎を発症したとの報告はない。 治療は副腎皮質ステロイド剂が有效である。 臨床症候，検査所見とも速やかに改善する，疼 痛はすぐに消失するが，末梢神経障害は軸索が 障害されるため後遺症として残ることが多い. 生命予後は他の全身性壊死性血管炎に比べると 良好である゙!. 本症の気管支喘息はアトピー型で あり, 本症の発症にアトピー素因, アレルギー 機序の関与が重要であることは間違いないが,
その病態の詳細は不明である.IgEを介するI 型 アレルギー機序, IgE免疫複合体によるI型アレ ルギー機序, 活性化好酸球や細胞傷害性T細胞に よる組織障害機序, IV型アレルギーによる肉芽 腫形成など複合的なメカニズムが作用している と考えられている．本症では中枢神経が炎症に より侵されることはないので，本症では末梢神 経が血管炎の標的となる何らかの機転が存在す ることが示唆される。

\section{2. アトピー性㾞髄炎}

\section{1）疾患概念}

我々は成人のアトピー性皮虚炎患者で四肢の

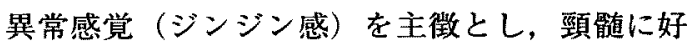
発する脊髄炎の存在を報告した ${ }^{5-7)}$ ・アトピー素 因を背景として発症する脊髄炎の意で,アトピー 性脊䯣炎 (atopic myelitis) という病名を提唱し ている，アトピー性疾患は頻度が高いので，ア トピー素因と脊䯣炎の間に有意な関連があるか が問題となる．様々な中枢神経疾患患者で血清 全IgE㧍よびアレルゲン特異的IgEを測定したと ころ, 健常対照に比し原因不明の脊䯑道炎でのみ 有意に血清高IgE血症の頻度, ダニアレルゲン特 異的IgE陽性率が高いことが判明した8)。このこ とは，アトピー素因と原因不明の春髄炎の発生 との間に何らかの関係があることを示唆する。

\section{2）全国臨床調査結果}

アトピー素因と脊䯣炎の発生との間に何らか の関連があることが示唆されたので, (1)原因不 明の脊髄炎で, (2)アトピー性疾患を合併するか， または高IgE血症とアレルゲン特異的IgEが陽性 （アトピー素因がある）,との基準で 2000 年に全 国調査を行って症例を集積した たす患者は当科で 49 例, 全国調査で 30 例あう た．全国調査例が少ないのは，全国例ではより 重症な例が寄せられ軽症例が十分には集められ なかったことと, 疾患単位としての認知がいま だ不十分なことによると思われる. 79 例の男女 


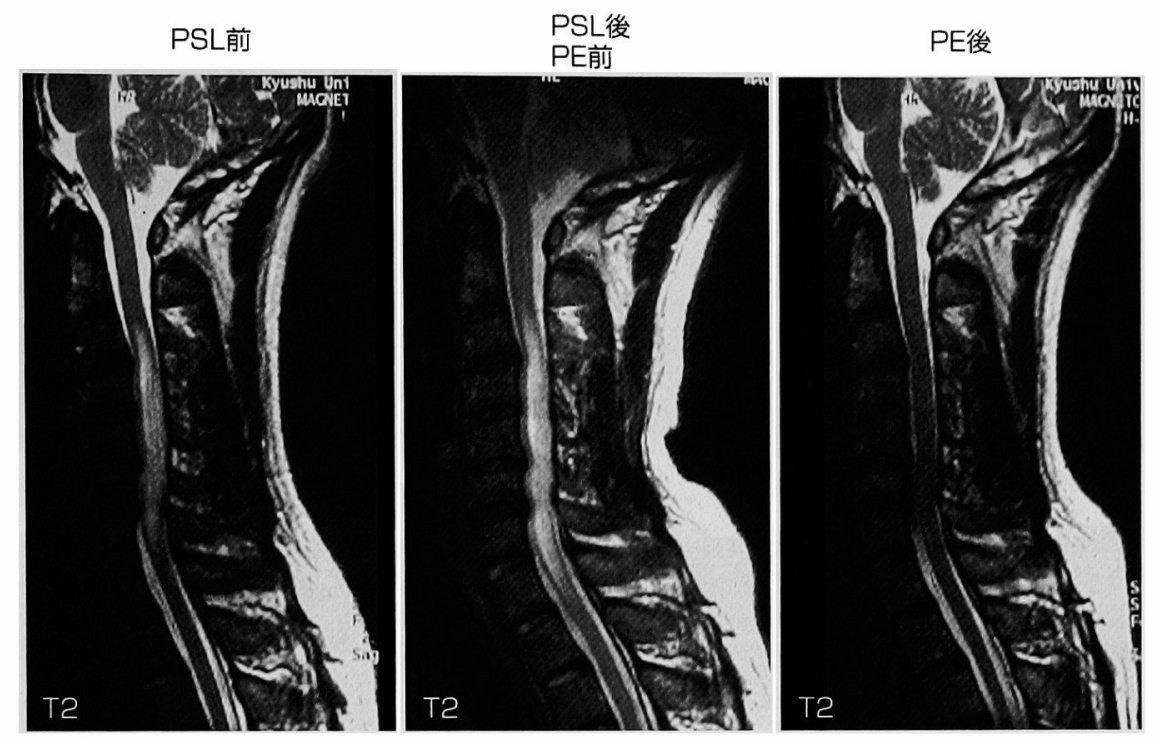

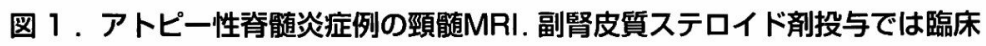
的には不変であったが, 画像的には悪化した. 血獎交換後ガドリニウム造影効 果が消失し, 感覚障害も改善した.

比は, 1 対 0.65 で男性にやや多く, 平均発症年齢 は $35.8 \pm 13.6$ 歳, $77 \%$ が 20 歳から 50 歳までの 発症であった. $73.4 \%$ にアトピー性疾患の合併を 認めた.その内訳は, $41.8 \%$ がアトピー性皮膚炎, $22.8 \%$ が気管支喘息, $27.8 \%$ がアレルギー性鼻炎・ 花粉症であった. 発症の様式は $60 \%$ が急性発症 であったが, その後は階段状の増悪ないしは動 摇性の経過をとる症例が $70 \%$ を占めた. 初発症 状は四肢の異常感覚が $74.5 \%$ を占め, 高度の脱 力は稀であった $(5.2 \%)$. 臨床症候から推定され た病巣は, 頸髄が $75.9 \%$ と最多で, この点は横 断性脊髄炎が胸髄に最も多いのと対照的だった.

検査所見ではMRI上 $58.2 \%$ で春髄病巣を確認 できた. 部位としては頸髄が $73.9 \%$ と最も高率 だった (図 1).ガドリニウム造影効果を $56.4 \%$ で認めた. 高IgE血症を $88.2 \%$ に, ヤケヒョウヒ ダニ特異的IgEを $90.9 \%$ に,コナヒョウヒダニ特 異的IgEを $88.3 \%$ に認めた. 末梢血好酸球增多は $57 \%$ にみられた.髄液検査が施行された 54 例の うち $26 \%$ で軽度の細胞増多を認めた. 14 例中
6 例 $(42.9 \%)$ で髄液でも $\operatorname{IgE}$ 值が高値だった.

\section{3）臨床像の特徵}

以上の所見から, 臨床像の特徴をまとめると, (1)アトピー性疾患が先行し, その増悪後に発症 することが多い, (2)高IgE血症を伴う, (3)ヤケヒョ ウヒダニ, コナヒョウヒダニなどに対するアレ ルゲン特異的IgEが陽性, (4)約半数で末梢血で軽 度の好酸球增多を伴う, (5)発症は急性ないし亜 急性だが, 慢性動摇性の長い経過をとる（病歴 が長いと発症の時点のことが不明確で慢性発症 にみえることもある), (6)四肢遠位部の異常感覚 (ジンジン感)を主徵とする, (7)四肢腱反射の立 進を伴うことが多いが, 明らかな運動麻痺や病 的反射の出現は少ない, (8)臨床症候からみた病 巣は頸髄が多い, (9)MRIでも頸髄に病巣が認め られることが多く, 典型的には頸髄後索寄りに 病巣がみられる, (10) MRI上の病巣は変動にそし く, ほぼ同じ大きさで長く存在する, となろう.

\section{4) 脊喊病理}

本症では脊髄腫瘍同様に孤発性に異常陰影が 


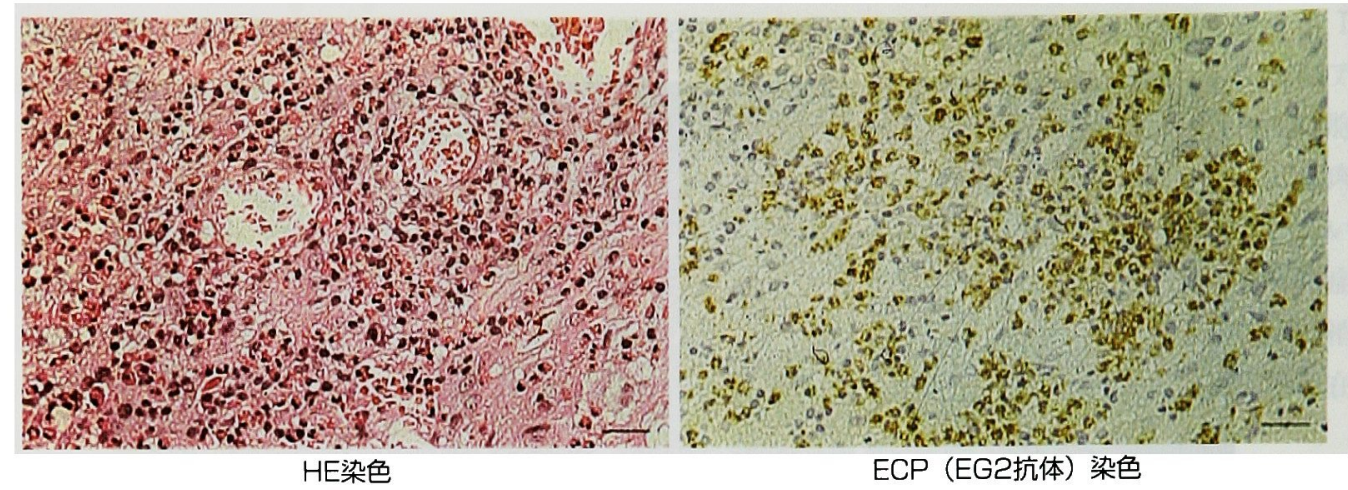

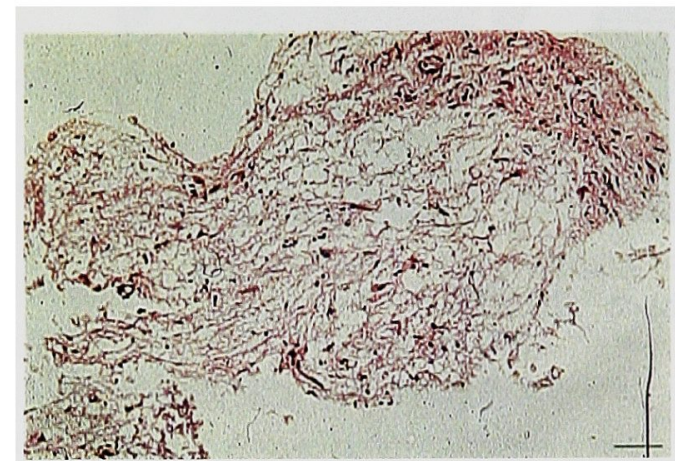

HE染色

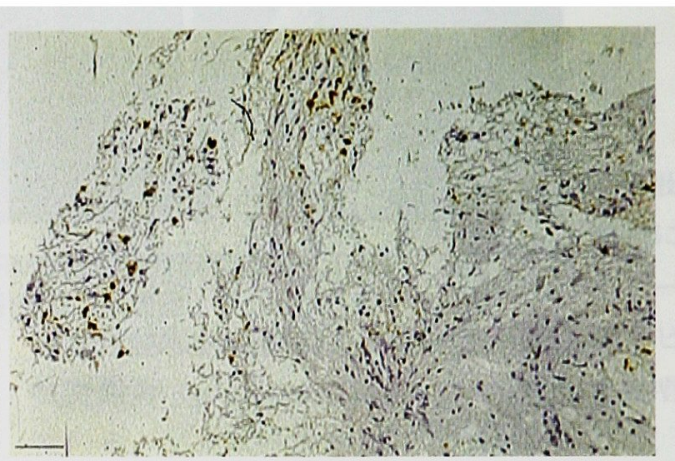

ECP (EG2抗体) 染色

図２．アトピ一性脊髄次症例の脊随生検標本の病理像. 上段は好酸球浸潤の著 明な例. eosinophil cationic protein (ECP) の著しい組織沈着を認める. 下段は好酸球浸潤の軽い例. しかし, ECPの組織沈着は明らか.

長く続くために脊骨道腫瘍を疑われて生検される 場合がある. 2000 年の全国調査では，脊髄病巣 が生検された，アトピー素因がある原因不明の 脊髄炎症例が 5 例集積された ${ }^{10}$. 脊髄炎発症から 生検までの期間は 4 カ月から約 2 年と長期に渡っ ていたが，いずれも好酸球浸潤を伴う著明な炎 症がみられ(図 2)，軸索も䯣鞘もともに脱落し ていた. 浸潤細胞はT細胞を主体としB細胞の浸 潤も伴っていた.T細胞では, 血管周囲性にはCD8 陽性T細胞を主とし, CD4 陽性T細胞もみられた。 実質内にはCD8 陽性T細胞のみが浸潤していた。 活性化好酸球の産物である eosinophil cationic proteinの組織沈着が認められた。血管壁自体の 破壊はほとんど見られないことから血管炎とは いえない, したがって, 本症は好酸球性脊髄炎
がその病理像であり, CD8 陽性 T細胞(細胞傷害 性 T細胞)や好酸球がエフェクターとなって, 䯣 鞘，軸索などの脊髄寒質を障害しているものと 考えられた，好酸球浸潤を伴う炎症性病巣であ る点では，気管支喘息やアトピー性皮周炎など の典型的なアレルギー性疾患と共通している.

\section{5）免疫学的特徵}

T細胞はIFN $\gamma$ やIL2 などを産生し細胞性免疫に 関与するTh1 細胞と, IL4, IL5, IL13 などを産 生し液性免疫に関与する $\mathrm{Th} 2$ 細胞に大別され, 両者の免疫バランスは様々な自己免疫疾患や炎 症性疾患の発生に関与する。アレルギー性疾患 はTh2 細胞が主として関与して発症する，アト ピー性脊髄炎について末梢血CD4 陽性 T細胞の細 胞内サイトカイン産生パターンを調ベることに 
より, INF $\gamma / \mathrm{IL}-4$ 比が健常対照より有意に低く， 末梢血ではTh2 にシフトした状態で脊髄炎を発 症していることが示された8).この点は, 中枢神 経䯣鞘を標的とする臓器特異的な自己免疫疾患 である多発性硬化症が再発時にTh1 シフトを呈 することと対照的である11).

一方, 髄液中細胞の細胞内サイトカイン産生 能を測定することは, 䯣液細胞数が少ないこと と, 髄液細胞が脆弱であることから, 従来困難 であったが, 我々は最近細胞增多のない例でも 髄液細胞内サイトカインを測定する方法を確立 した. 本法によれば, 多発性硬化症では再発時 に非炎症性中枢神経疾患に比べて著明な Th1 シフトを示した ${ }^{12)}$. 不思議なことにアトピー性脊 髄炎例でも同様に䯣夜細胞では Th1 シフトがみ られた ${ }^{12)}$.つまり,アトピー性脊髄炎では末梢血 はTh2 シフトを示すが, 䯣液ではTh1 シフトが みられる。

6) 診断

(1)原因不明の脊髄炎で, (2)アレルギー性疾患 が先行するか, または高IgE血症とアレルゲン特 異的IgEを伴い, (3)その他の疾患が除外されると きに本症を疑う。たとえば，ヒトの中枢神経炎 症性疾患で最も頻度の高い多発性硬化症の除外 は不可欠である.脳MRI上多巣性大脳白質病宩 を伴う例 (McDonaldの診断基準 ${ }^{13)}$ ：MRI上 9 個 以上）は，アレルギー性疾患を合併していても 多発性硬化症と考えたほうがよい。

\section{7）治療}

アトピー性脊髄炎自験 26 例の 42 回の各種免 疫療法の結果 (図 3) をまとめると, 副腎皮質ス テロイド剤より血獎交換の有効率が高く ${ }^{14)}$, 免疫 グロブリン静注療法は両者のより低い有効率だっ た. ただし, 血槳交換は効果が1〜数力月と長続 きしないことが多いため, 血漿交換に副腎皮質 ステロイド剤や免疫グロブリン静注を併用し治 療効果が持続する例がある、いわゆる抗アレル ギー薬は脊髄炎には効果は乏しいようである. ただ,アレルギー性疾患の増悪後に発症ないし

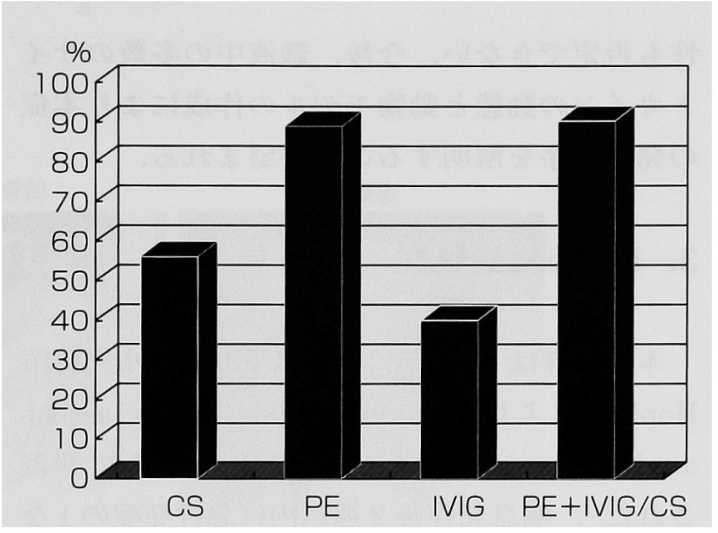

図 3．アトピー性瓷酭炎における各種免疫療法の 効果. 神経学的所見の改善率を示す. $C S=$ 副腎皮 質ステロイド剤. $P E=$ 血漿交換. IVIG=免疫グロ ブリン静注.PE+IVIG/CS=血漿交撸後に免疫グ ロブリン静注または副腎皮質ステロイド剤を追加.

増悪することが多いので，合併するアレルギー 性疾患のコントロールは重要である.

\section{8）発症機序}

䯣液中でもIgEが高值であったこと, 及び脊髄 病巣にも好酸球が浸潤していたことは，中枢神 経内でも Th2 細胞が働いてアレルギー機序によ り脊髄炎を起こしていることを示唆する．アト ピー素因のある個体では, 幼少児期より腸管, 皮膚，気道など様々な組織に次々とアレルギー 性炎症を起こす．このようなアレルギーマーチ の一環として中枢神経が障害される可能性があ る.

他方, 直接的にアレルギー性機転で脊髄炎が 起こっているにしては, アトピー性脊髄炎の発 症はアトピー性疾患患者の一部に限られている. また髄液IgE值は血清IgE值と正の相関がみられ ることから,髄液IgEは髄腔内局所で産生された ものよりはむしろ炎症により血液脳関門が破 綻して末梢血から漏出したものが主体である可 能性もある.したがって,アトピー性脊髄炎は, アレルギー性疾患に伴う免疫バランスの異常に 起因する蔵器特異的な自己免疫疾患である可能 
性も否定できない，今後，髄液中の多数のサイ トカインの動態と動物モデルの作成により本症 の発症機序を解明することが望まれる。

\section{Hopkins症候群}

本症侯群は 1974 年にオーストリアの小児科医 Hopkinsにより poliomyelitis-like illness associated with acute asthma in childhoodとして報告 された ${ }^{1)}$. 喘息発作後 2 週以内に急性発症の 1 な いし 2 肢の弛緩性麻瘏を呈する。これまでに報 告された 30 余例の臨床像の特徵は, (1) 10 歳末 満にみられることが大部分 (平均 5.7 歳)，(2)男 児に多い（男女比は約 2 对 1)，(3)喘息の発作後 生じる (平均 5.9 日で発作の重症度は無関係),

(4)急性発症, (5)弛緩性麻瘦（単麻疸が $80 \%$, 残 りは対麻痺や片麻痺), (6)䯣液に炎症反応(的半 数)，(7)回復にそしいなどである15).

脊䯣病巣は, $40 \%$ が頸䯣に, $60 \%$ が腰䯣にみ られる，笳萎縮が高度で回復傾向に乏しく，針 筋電図で線維束性収縮電位等の脱神経所見がみ られ，筋生検でも神経原性パターンを呈するこ となどより，責任病巣は脊䐈前角運動ニューロ ンと推定されている ${ }^{15)}$. 脊髄MRIでも前角にT 2 高信号域が見られる例がある。しかし，MRI で脊髄前側索の白質に病巣を認めた例, 体性感 覚誘発電位 (SEP) でも異常が見られた例（脊䯣 後索病変を示唆する)，病的反射を伴った例(錐 体路にも障害が及んでいる), 数力月以上経過し てから徐々に脱力が改善していった例（前根が 主病巣と考えられる）などの報告もあるので, 前角運動ニューロンのみが選択的に障害される わけではなく，障害範囲にはもっと拡がりがあ ることがわかる.

また，我々は本症の成人例を初めて報告し た ${ }^{16)}$. その後に本症と前述のアトピー性脊䯣炎の 移行例と思われる成人例も報告されている。こ のことは本症の発症が必ずしも思春期前の小児 に限定しないことを示唆している.
現在まで特定の病原体が共通して検出された ことはなく，ウイルスなどによる直接的な運動 ニューロンの感染症は否定的である. 本症の脊 骨道病理所見の報告はないので, 発症機序は推測 の域を出ないが, 病像が突発完成することが多 いため、アレルギー機序に関連した瓷髄前角の 微小循環障害やアレルギーに関連したサイトカ インによる神経障害が想定されている.

\section{4. 平山病}

\section{1）疾患概念}

平山病は 1963 年に東京大学のHirayama ${ }^{17)} ら に$ より記載された 10 代から 20 代前半までの若年 者に好発する上肢遠位筋萎縮症である．責任病 巣は下部頸䯣前角運動ニューロンである，運動 ニューロン疾患とは異なり, 発病後 2 ないし 3 年で進行は停止性となる。

\section{2）臨床像}

男性の䍜患頻度が高い(男女比は 20 対 1) ${ }^{18)}$. 筋萎縮は一側性ないしは非対称性であることが 大部分である（図 4)．慢性ないし亜急性に発症 し, 発病後 $2 \sim 3$ 年間進行し, 停止性となる. た だ，まれに 20 代，30 代になってから再び進行す ることがある、筋萎縮, 脱力は䯑有節性に起こり, 第 7 , 第 8 頸髄節, 第 1 胸䯣節が障害される. 寒 泠時に筋脱力は增覀 (寒冷麻疸) することが多 い．指を伸展した際に指の細かい震えがみられ るなどの特徴がある，針筋電図上は，障害髄節 はもっと広範囲に及ぶ. MRIでは頸部前屈位で， 9 割弱で脊椎後部の静脈叢の拡大と下部頸髄の前 方移動がみられ ${ }^{19)}$, 下部頸䯣は扁平化する.

\section{3）発病機序}

1 例の慢性期の剖検報告では, 下部頸髄の前角 連動ニューロンの脱落がみられている ${ }^{20)}$. MRI 所見および剖検所見より，本症は頸部前屈に伴 う下部頸骾の機械的圧迫のため生じるflexion myelopathyと考えられてきた.下部頸䯣に反復 性に加えられた圧迫とそれによる微小循環障害 

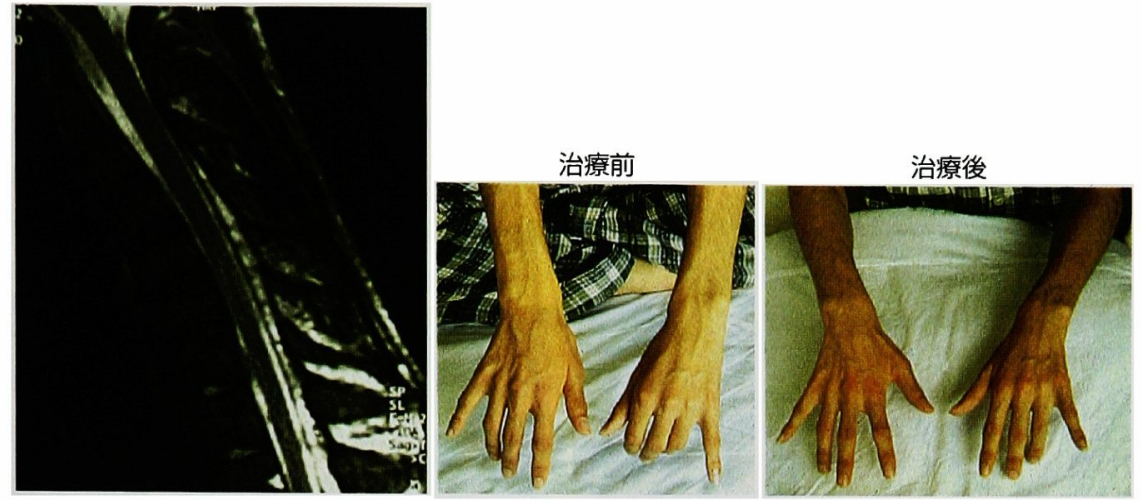

図 4. 気道アレルギーを伴う平山病例の血熽交換による麻痺の改善. MRIは頸 部前屈位を示す．本例では硬膜の前方移動は軽度.

により，それらにもっとも弱い前角運動ニュー ロンが障害されるというものである.頸椎カラー の装着により約 3 割で進行が停止性となること もこの仮説を支持する ${ }^{18)}$.

\section{4）アレルギー機序の関与}

平山病の機械的因子説については, 次のよう な反論がある. MRI上の脊椎後部静脈叢のうっ 滞と下部頸䯣の前方移動は, 平山病の全例でみ られるわけではないこと, 健常者でも同様の所 見がみられる場合があることなどである，さら に, 平山病は全国疫学調査によれば, 近年発症 が著明に増加しているが，これは機械的因子説 では説明できない，本症が日本人に多いことも 機械的因子説では説明が難しい．また微小循環 障害が想定されているが, 脊髄梗塞とは病理像 は全く異なる。

そこで,我々は最近の平山病自験連続 11 例で アトピー素因の関与を調査した. 11 例中 10 例で アレルギー性鼻炎, 花粉症, 気管支喘息などの 気道アレルギーの合併がみられた ${ }^{21,22)}$. 不思議な ことに, アトピー性皮膚炎は 1 例で既往があっ たのみで, 平山病発症時にアトピー性皮膚炎に 罹患していたものはなかった. 11 例全例でアレ ルゲン特異的IgEが陽性で, 高IgE血症は 6 例で, 好酸球増多は 9 例でみられた.この結果, 平山
病では健常対照より気道アレルギーの合併率, ダニアレルゲン特異的IgE陽性率 (73\% 対 33\%) のいずれもが有意に高值だった. さらに，末梢 血CD4 陽性 $\mathrm{T}$ 細胞の産生する細胞内サイトカイン のパターンを調べると, 有意に平山病では健常 対照より IFN $\gamma / \mathrm{IL}-4$ 比が低く, Th2へシフトし ていた. 我々の報告に続いて他施設からも平山 病では特にその増悪期に血清IgEが高值であると の報告もなされた. 以上の成績は平山病の発症 にアトピー素因の関与があることを強く示唆す る.

5）平山病の免疫療法の可能性

平山病は臨床的によくまとまった一疾患単位 と考えられるが, 発症機序からみた場合にheterogeneousである可能性は否定できない. 我々 は従来の機械的因子説のみでは平山病の臨床疫 学的特徴の全てを説明することは困難であるこ とから, 機械的因子に加えて免疫機序の関与を 考えている.アトピー性疾患が冠動脈不全など の循環障害の危険因子とする報告もあることか ら，アレルギー機序の関与する循環障害, たと えば血小板IgE受容体を介する血小板の活性化に よりヒスタミンやサイトカイン, platelet activating factorなどが放出され, 機械的要因により血 液のうっ滞しやすい下部頸髄で前角の微小循環 


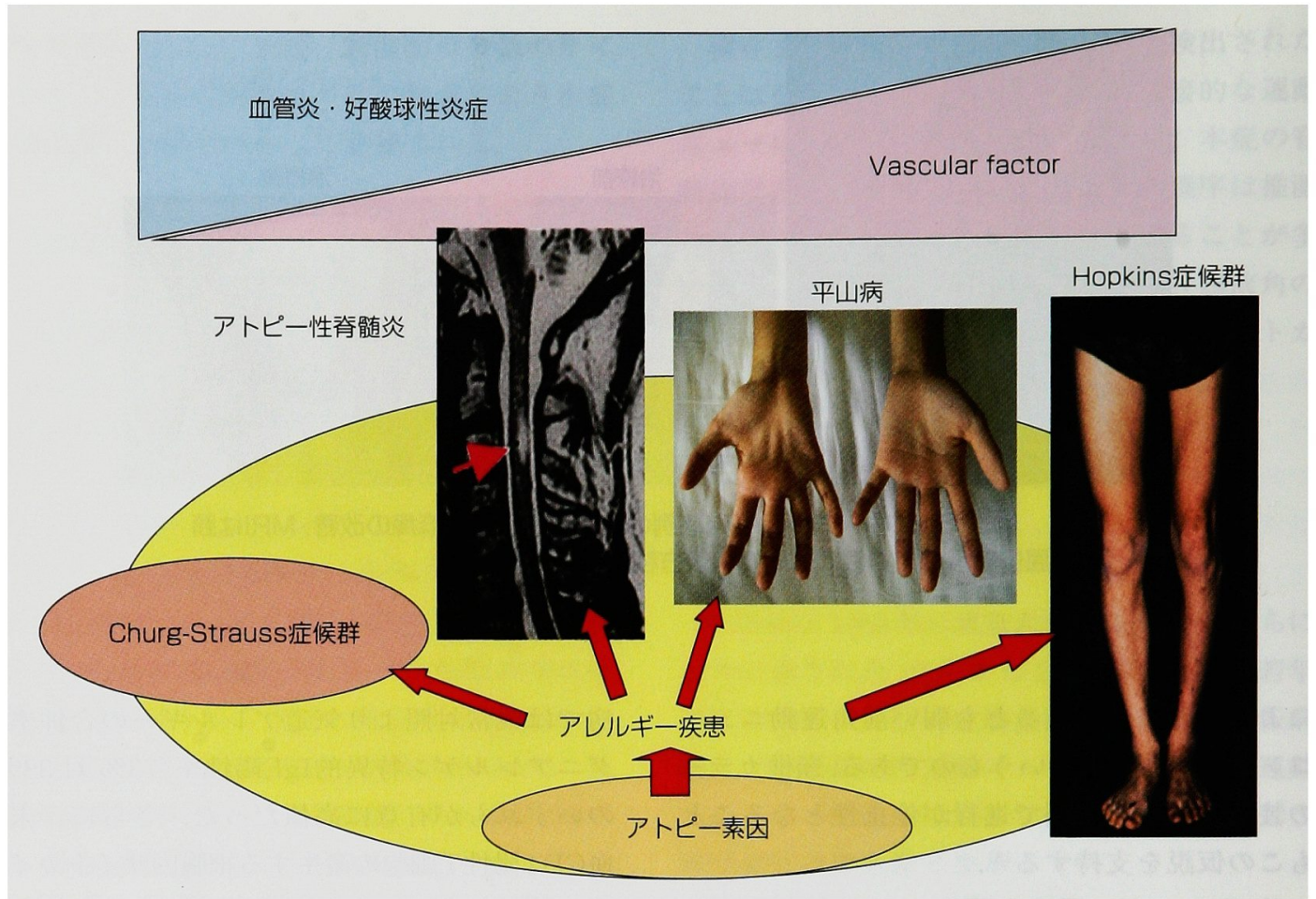

図 5. アレルギ一性疾患に関連した神経障害の病弉の発症譏序についての仮説.

表．アレルギー疾患と関連した神経障害の比較

\begin{tabular}{|c|c|c|c|c|c|}
\hline & 好発年齢 & $\begin{array}{c}\text { 先行する } \\
\text { アレルギー疾患 }\end{array}$ & $\begin{array}{c}\text { アレルギー疾患 } \\
\text { と発症時期 }\end{array}$ & 発症の様式 & 病変部位 \\
\hline Hopkins 症候群 & $\begin{array}{c}\text { 学童期 } \\
\text { (平均 } 6 \text { 歳) }\end{array}$ & 喘息 & $\begin{array}{l}\text { 発作後 } \\
1 \text { 週以内 }\end{array}$ & 突発～急性 & $\begin{array}{c}\text { 脊隨前角運動 } \\
\text { ニューロン }\end{array}$ \\
\hline 平山病 & $\begin{array}{c}10 \text { 歳代 } \\
\text { (平均 } 15 \text { 歳) }\end{array}$ & アレルギ一性鼻炎 & 不明 & 慢性～亜急性 & $\begin{array}{l}\text { 頸髄前角運動 } \\
\text { ニューロン }\end{array}$ \\
\hline アトピー性脊髓次 & $\begin{array}{c}20 \sim 30 \text { 歳代 } \\
\text { (平均 } 35 \text { 歳) }\end{array}$ & アトピー性皮虐炎 & $\begin{array}{c}\text { 増悪後 } \\
\text { 数日数週 }\end{array}$ & 急性～亜急性 & 頸䯣後索 \\
\hline $\begin{array}{c}\text { Churg-Strauss } \\
\text { 症候群 }\end{array}$ & $30 \sim 40$ 歳代 & 喘息 & $\begin{array}{c}\text { 発症後は } \\
\text { 喘息は軽減 }\end{array}$ & 急性 & 多発性単神経资 \\
\hline
\end{tabular}

障害や炎症を起こすのかもしれない。そこで，

我々は発症後 3 年以内の比較的早い時期の平山 病患者 2 例において, 血漿交換を試みた. 2 例と も血漿交換後に血清 $I g E$ 值の低下とともに指の震 えの消失, 脱力の改善を認めた ${ }^{23)}$.このことは平 山病の少なくとも一部の発症に免疫・アレルギー 機序が関与していることを示唆する.
おわりに

本稿で取り上げた疾患の特徵を表にまとめた. アトピー性脊䯣炎ではアトピー性皮䖉炎, Hopkins症候群では気管支喘息, 平山病ではアレル ギー性鼻炎, と先行するアレルギー性疾患は異 
なるものの，アトピー性疾患が先行して脊髄障 害を起こすという点では共通している。これら の疾患とアレルギー性疾患の関連が全くの偶然 としたら, 先行するアトピー性疾患に一定の傾 向があることや脊髄内で障害される部位に一定 の傾向があることを説明することは困難である. 図 5 に示すように，好酸球性炎症やアレルギー に伴う血管障害の要素が複合してそれぞれの病 態が生じていると考えている.今日, かが国で のアレルギー性疾患の増加は著しいので，アレ ルギー性疾患に伴う中枢神経障害が今後増加す る可能性は高いと思われ，アレルギー患者にお ける麻瘏症状や感覚異常の出現に留意する必要 があろう。

\section{文 献}

1) Hopkins IJ : A new syndrome : poliomyelitis-like illness associated with acute asthma in childhood. Aust Paediatr J $10: 273-276,1974$.

2) Churg J, et al : Allergic granulomatosis, allergic angitis, and periarteritis nodosa. Am J Pathol $27: 277-301,1951$.

3) Hattori N, et al: Clinicopathological features of ChurgStrauss syndrome-associated neuropathy. Brain 122: 427-439, 1999.

4) Nagashima T, et al: Clinicopathological studies of peripheral neuropathy in Churg-Strauss syndrome. Neuropathology $22: 299-307,2002$.

5) Kira J, et al : Acute myelitis associated with hyperIgEemia and atopic dermatitis. J Neurol Sci 148 : 199-203, 1997.

6) Kira J, et al: Acute myelitis with hyperIgEaemia and mite antigen specific IgE : atopic myelitis. J Neurol Neurosurg Psychiatry 64 : 676-679, 1998.

7) Kira J. et al: Clinical, immunological and MRI features of myelitis with atopic dermatitis (atopic myelitis). J Neurol Sci $162: 56-61,1999$.

8) Horiuchi I, et al: Th1 dominance in HAM/TSP and the optico-spinal form of multiple sclerosis versus $\mathrm{Th} 2 \mathrm{domi-}$ nance in mite antigen-specific IgE myelitis. J Neurol Sci $172: 17-24,2000$.
9) Osoegawa M, et al : Myelitis with atopic diathesis : a nationwide survey of 79 cases in Japan. J Neurol Sci 209: 5$11,2003$.

10) Osoegawa M, et al : Eosinophilic myelitis associated with atopic diathesis : a combined neuroimaging and histopathological study. Acta Neuropathol 105 : 289-295, 2003.

11) Ochi $\mathrm{H}$, et al: $\mathrm{Tcl} / \mathrm{Tc} 2$ and $\mathrm{Th} 1 / \mathrm{Th} 2$ balance in Asian and Western types of multiple sclerosis, HTLV-I-associated myelopathy/tropical spastic paraparesis and hyperIgEaemic myelitis. J Neuroimmunol 119:297-305, 2001.

12）村井弘之, 他：視神経脊䯣型抢よび通常多発性硬化症に

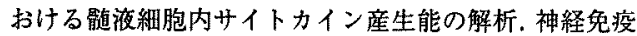
学 $11: 61,2003$.

13) McDonald WI, et al: Recommended diagnostic criteria for multiple sclerosis: Guidelines from the international panel on the diagnosis of multiple sclerosis. Ann Neurol $50: 121-127,2001$.

14）越智博文, 他：アトピー性脊殖炎の治療成績についての 検捨. 神経免疫学 $10: 128-129,2002$.

15）吉良潤一：Hopkins症候群の疾患分類学的位置とその今 日的意義. 神経内科 $56: 32-40,2002$.

16) Horiuchi $L$ et al:Acute myelitis after asthma attacks with onset after puberty. J Neurol Neurosurg Psychiatry 68: $665-668,2000$.

17) Hirayama $\mathrm{K}$, et al : Juvenile muscular atrophy of unilateral upper extremity. Neurology $13: 373-380,1963$.

18) Hirayama $\mathrm{K}:$ Juvenile muscular atrophy of distal upper extremity (Hirayama disease). Intern Med $39: 283-290$. 2000.

19) Hirayama $K$, et al: Cervical dural sac and spinal cord in juvenile muscular atrophy of distal upper extremity. Neurology 54 : 1922-1926, 2000.

20) Hirayama $\mathrm{K}$, et al : Focal cervical poliopathy causing juvenile muscular atrophy of distal upper extremity : a pathological study. J Neurol Neurosurg Psychiatry 50 : 285-290, 1987.

21) Kira J, et al : Juvenile muscular atrophy of the distal upper limb (Hirayama disease) associated with atopy. J Neurol Neurosurg Psychiatry $70: 798-801,2001$.

22）越智博文, 他: 若年性上肢遠位筋萎縮症における臨床. 免疫アレルギー学的検討. 神経免疫学 $11: 63.2003$.

23) Ochi $\mathrm{H}$, et al : Juvenile muscular atrophy of distal upper extremity associated with airway allergy : two cases successfully treated by plasma exchange. J Neurol Sci 206 : 109-114, 2003. 